\title{
構造用合板と木材のビス接合部のせん断における クリープ限度の推定*1
}

\author{
小川敬多*2，小林研治*2
}

\author{
Estimation of Creep Limit of Screw Joints between Timber \\ and Structural Plywood under Constant Shear Loading*1
}

\author{
Keita OgawA*2 and Kenji KoBayashi*2
}

\begin{abstract}
In a situation where the development of various novel wooden structural materials continues, it becomes necessary to understand the creep properties of wooden screw joints under shear loading. Therefore, shear creep tests for joint specimens were conducted. Screw joint specimens consisting of solid wood (Japanese cypress) and structural plywood made of softwood were used for the tests. The tests were conducted in a testing room controlled at $20{ }^{\circ} \mathrm{C}$ temperature and $65 \%$ relative humidity. The shear load was applied for over 40000 hours. The stress levels were determined as $39.0-70.2 \%$ of the standard yield load obtained by monotonic-loading tests. The slip-time relationships were obtained by the tests. This study proposed a method for estimating the creep limit by analyzing the slip-time relationships. By applying the proposed method, the creep limit of the screw joint specimens was estimated as $27.6 \%$ of the yield load.
\end{abstract}

Keywords : screw joint, long-term load, shear, creep limit.

様々な木質構造用新部材の開発が進んでいる昨今，ビスによる木材と木質面材料の接合部にお いても，長期的なせん断力が掛かることが想定されるようになっている。これを踏まえて，ビス 接合部のせん断におけるクリープ特性を把握する必要があると考え, せん断クリープ試験を実施 した。主材をヒノキ, 側材を構造用針葉樹合板としたビス接合部試験体を用いて, 室温 $20{ }^{\circ} \mathrm{C}$, 湿度65\%に制御された恒温恒湿室にて, 40000時間を超えるせん断負荷を与えた。応力レベルは, 降伏耐力を基準值として39.0〜 70.2\% とした。せん断負荷時間の増加にともなって変位が増加す る挙動を示した。本研究では，測定された変位一時間関係をもとに，クリープ限度を推定する方 法を提案した。提案した方法を用いると, 本試験でのビス接合部のクリープ限度は, 応力レベル $27.6 \%$ であることが推定された。

\section{1. 緒言}

木材の構造物への利用に対する機運が高まるな か, 様々な外力に対して安全な構造物を設計するこ とが必須である。木質構造の構造特性には, 接合部

*1 Receaved January 22, 2020 ; accepted April 22, 2020.

*2 静岡大学学術院農学領域 College of Agriculture, Academic Institute, Shizuoka University, Shizuoka 422-8529, Japan

Corresponding author: K. Ogawa (ogawa.keita@ shizuoka.ac.jp)
の強度性能が支配的となることが良く知られてお り, したがって, 接合部の強度性能の把握は不可欠 である。現代の木質構造では様々な種類の接合部が 用いられているが, ビスを用いた接合部は，施工性 の良さや引き抜き抵抗の大きさ等を利点として，国 内外で多く見られようになってきた。その利用とし ては, 例えば, 耐力壁におけるパネル材の張り付け1) や，木質ラーメン構造における柱と梁の接合 ${ }^{2}$, 直 交積層板 (CLT) 壁体の脚部の留め付け等が挙げ られ，これらは地震や台風等の短期的に作用する外 力を想定したものであった。ところが近年では，例 えば村上ら ${ }^{4)}$ によるフランジとウェブ合板をビス接 合した充腹梁の開発や, 藤田ら ${ }^{5)}$ による単板積層材 
のフランジとウェブをビス接合したストレストスキ ンパネルの開発が試みられている。これらを想定し た場合では，接合部に長期的なせん断力が作用する ことから, 接合部での長期荷重に対する変形挙動を 把握することが必要となる。しかしながら, ビス接 合部の短期的なせん断力下における研究例は数多く 存在するものの ${ }^{6)}$, 長期的なせん断力下においては

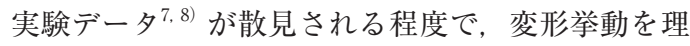
解するのに十分な知見を得られているとは言い難 $\omega^{9)}$ 。

本研究は, ビス接合部の長期的なせん断力下にお ける変形挙動の把握を目的としており, 特に, クリ ープ限度に主眼を置いたものである。ビス接合部試 験体に対して40000時間を超える長期の載荷試験を 実施し, 時間の増加に伴う変形の挙動を解析するこ とによって, クリープ限度を推定した。クリープ限 度は“永久に破壊することなく継続載荷に耐えうる 応力度または荷重の最大值”と知られているが10), その值を決定するための明確な定義が存在しない。
機械工学分野の資料では“10000時間に0.1\%のクリ ープひずみを生ずるような応力”という記述が見ら れるが ${ }^{11)}$ ，木材強度学の分野では, 沢田 ${ }^{12)}$ は“単位 時間当たりのひずみ増加量が一定となる時のひずみ 量が, 静的比例限度におけるひずみの計算值に等し くなる荷重”と提案しており, 桑村 ${ }^{13)}$ は“建物の 耐用年数内で不安定クリープ領域（いわゆる三次ク リープ）に入らない応力の上限”と提案している。 一方, 杉山 ${ }^{10,14)}$ は “継続荷重を受けてもクリープ が休止する応力度または荷重の最大值”と定義し, また, クリープ限度を求める解析手法として, クリ ープ関数（時間依存による変形量と載荷初期の変形 量の比）を用いる方法を提案した。ある経過時間に おけるクリープ関数と応力レベルの関係を図示した 際に，傾斜の異なる二つの折れ線が現れることを発 見し，その交点をクリープ限度と定めた。この杉山 の方法は近年に至っても支持されており, 例えば, 松本ら ${ }^{15)}$ による製材および集成材, 中島 ${ }^{16)}$ や松本 ら ${ }^{17)}$ による単板積層材, 荒武ら ${ }^{18)}$ や高梨ら ${ }^{19)}$ によ
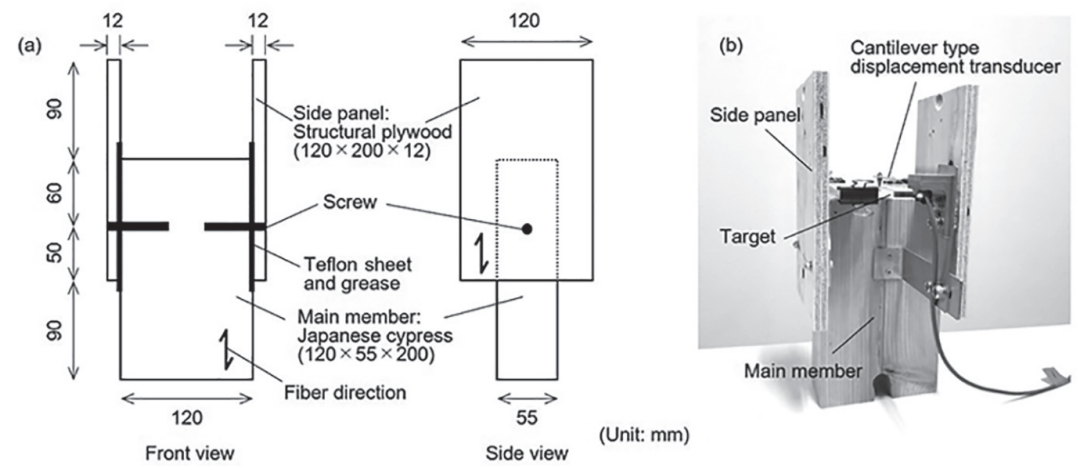

Fig. 1. Screw joint specimen.

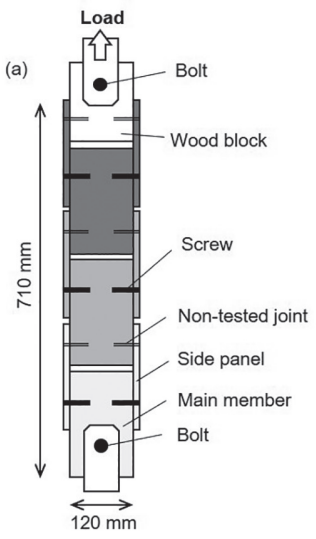

(b)

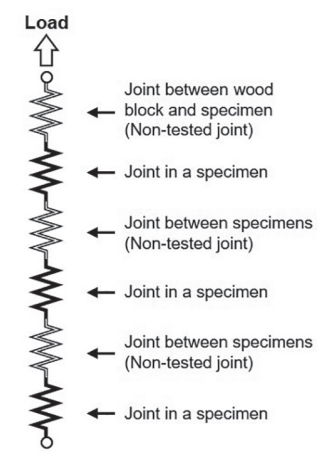

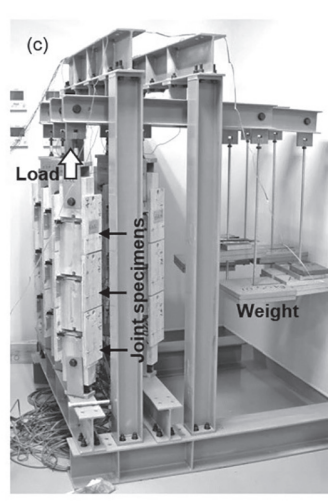

Fig. 2. Creep test specimen and experimental setup. 
るCLTに対して適用された実績がある。

本報で筆者らが試みたクリープ限度の推定方法 （詳細は後述）は，既往の提案とは定義や值の決定 方法において違いがみられ，40000時間超という長 期間で収録された変形挙動のデータを活かしたもの である。なお, 木材の粘弾性挙動を表現するうえで, バネとダッシュポットを用いたモデル20)を適用す ることが一般的になされており，木質接合部におい ても，Jang ら ${ }^{21,22)}$ によって適用された例がある。 しかしながら, 本研究で得られた試験結果に対して, バネとダッシュポットを用いた四要素モデル等の適 用を試みたものの, その適合性が低かったことから， 本報ではこれに関する考察を行わなかった。

\section{2. 試験体と試験方法}

\section{1 せん断クリープ試験}

ビス接合部試験体を Fig. 1 に示す。主材には寸法 $120 \times 55 \times 200 \mathrm{~mm}$ のヒノキ材 (Chamaecyparis obtusa Sieb. et Zucc.) を用いた。密度の平均值と標準偏差 は $498 \pm 23 \mathrm{~kg} / \mathrm{m}^{3}$, 含水率は $12.8 \pm 0.2 \%$ でった。 側材には $120 \times 200 \times 12 \mathrm{~mm}$ の構造用針葉樹合板 (5 プライ, 表層: ヒノキ, 内層: スギ, JAS 特類 2 級) を用いた。密度と含水率はそれぞれ $501 \pm 18 \mathrm{~kg} /$ $\mathrm{m}^{3}, 10.8 \pm 0.3 \%$ であった。Fig. 1 (a) に示すように, 主材に対して両側から 2 枚の側材で挟み込み, それ ぞれ 1 本のビスを用いて接合した。ビスは長さ $41 \mathrm{~mm}$, 呼び径 $4.2 \mathrm{~mm}$, 頭部径 $9.0 \mathrm{~mm}$ の耐力壁ビ ス（BX カネシン(株)製，KS4041）を用いた。主材 一側材間の摩擦を抑えるために, 厚さ $0.1 \mathrm{~mm}$ のテ フロンシート 2 枚を挟み込み, また，そのテフロン シートの間にはグリースを塗布した。

クリープ試験は Fig. 2 に示すように実施した。 Fig. 2 (a) で示すように, ビス接合部試験体 3 体を 直列に繋げて 1 組とし（図中では, 色の濃淡で別々 の接合部試験体であることを示す), これを Fig. 2 (c) で示すようにてこ式のクリープ試験機に 設置した。具体的には，一番下の接合部試験体の主 材を試験機下部とボルトで接合し，側材を中央の接 合部試験体の主材と接合した。この接合部は力を伝 達させることのみを目的としたもので, 本研究の接 合部の解析の対象ではない（図中では Non-tested joint と称し, 二重線で示す)。なお, この接合部で は上記と同じビスを片側 2 本ずつ用いて留め付け た。同様に, 中央の接合部試験体の側材を一番上の 試験体の主材と接合し，また，一番上の接合部試験 体の側材を, 力の伝達および側材の開閉防止を目的 として，木製ブロック（寸法： $120 \times 55 \times 200 \mathrm{~mm}$ )
と接合した。木製ブロックを試験機とボルトで接合 し，ここを加力点として，図のように鉛直上向きに 載荷した。これをバネモデルで示すと, Fig. 2 (b) のようになる。このように，3体の接合部試験体に 同じ大きさのせん断力が作用するセットアップを構 築した。各接合部試験体において, Fig. 1（b）に示 すように，主材にカンチレバー式変位計（(株)東京 測器研究所製, CE-10), 側材に変位計ターゲット を取り付け，主材一側材間のスリップ変位を測定し た。

載荷荷重は, $0.83 \mathrm{kN}, 1.11 \mathrm{kN}, 1.39 \mathrm{kN}$ の 3 条 件とした。なお，これらは過去に同じ仕様の接合部 試験体を用いた静的せん断試験した際8, 23) に得られ た長期許容せん断耐力 $(1.39 \mathrm{kN})$ に対して，0.6倍, 0.8倍，1.0倍した值である。ただし，接合部試験体 に作用する応力レベルの值は，次節および次章で記 す単調加力試験結果に基づてクリープ試験後に決 定した。試験体数は各条件で 3 体ずつ, 計 9 体とし た。試験体の載荷荷重（すなわち, せん断力）, 降 伏耐力, 応力レベルを Table 1 に示す（降伏耐力, 応力レベルの值については後述)。なお, Fig. 2 (c) では本報で研究対象としなかった試験体も一緒に写 っている。試験は室温 $20{ }^{\circ} \mathrm{C}$, 湿度 $65 \%$ に制御され た恒温恒湿室 ${ }^{24)}$ で実施した。試験開始は2014年11 月12日であり，試験終了は2019年 6 月13日とした。 載荷時間は40167時間であった。デー夕収録にあた って, 試験開始から 15 分間は 3 秒毎, 続く 5 分間は 20 秒毎, 続く 25 分間は60秒毎, 続く 90 分間は 5 分毎, 続く10時間は30分毎と順次収録間隔を増やしてい き，以降は 1 時間毎にデータを収録した。

\section{2 単調加力試験}

クリープ特性を考察するうえで, 試験体に作用し た応力レベルを決定する必要がある。そこで本研究 では, クリープ試験終了後の試験体を用いて単調加 力試験を実施し, 応力レベルの基準值を求めること

Table 1. Applied load, yield load, and stress level for each joint specimen.

\begin{tabular}{lrrr}
\hline \hline Specimen & $\begin{array}{r}\text { Applied load } \\
P_{a}(\mathrm{kN})\end{array}$ & $\begin{array}{r}\text { Yield load } \\
P_{y}(\mathrm{kN})\end{array}$ & $\begin{array}{r}\text { Stress level } \\
(\%)\end{array}$ \\
\hline $\mathrm{a}$ & 0.834 & 2.14 & 39.0 \\
$\mathrm{~b}$ & 0.834 & 2.10 & 39.7 \\
$\mathrm{c}$ & 0.834 & 1.86 & 44.8 \\
$\mathrm{~d}$ & 1.112 & 2.39 & 46.5 \\
$\mathrm{e}$ & 1.112 & 2.34 & 47.5 \\
$\mathrm{f}$ & 1.112 & 1.76 & 63.2 \\
$\mathrm{~g}$ & 1.390 & 2.22 & 62.6 \\
$\mathrm{~h}$ & 1.390 & 2.20 & 63.2 \\
$\mathrm{i}$ & 1.390 & 1.98 & 70.2 \\
\hline
\end{tabular}




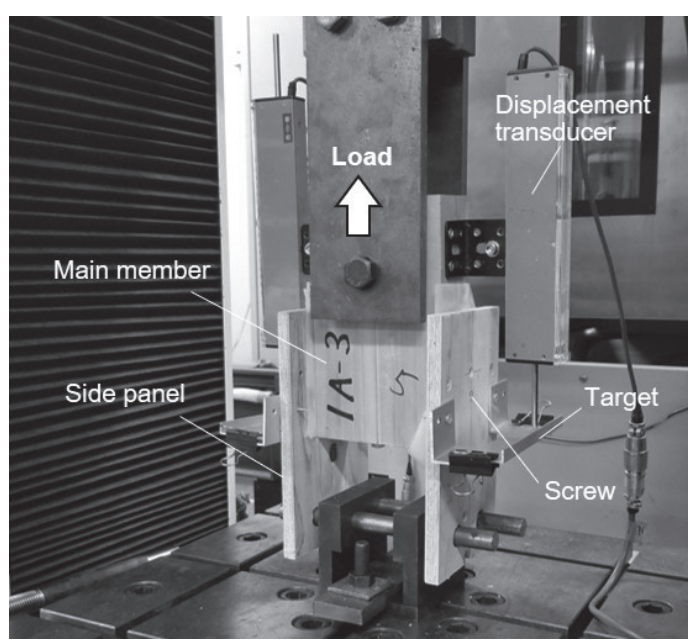

Fig. 3. Experimental setup for the monotonic-loading test.

とした。クリープ試験終了後, 接合部試験体のビス を取り外し，Fig. 1 (a) における上方向に $20 \mathrm{~mm}$ ず らした箇所に, 新品のビスを打ち直した。すなわち, クリープ試験と同じ材料で, 載荷履歴を無視できる ビス接合部試験体を作製した。この試験体を Fig. 3 に示すように, 万能材料試験機（(株)島津製 作所製，AG-1 250kN）を用いて単調加力した。側 材の下部は丸鋼を介して試験機と固定し，主材上部 にM16ボルトを介して上向きに加力した。加力速 度は $5 \mathrm{~mm} / \mathrm{min}$ とし, 最大荷重に到達後, それの 80\%に低下するまで負荷を続けた。せん断力は，口 ードセル（(株)島津製作所製，SFL-50kNAG）の読 み取り值とした。また，主材一側材間の変位を試験 体两面に取り付けた変位計 ( (株) 東京測器研究所製, SDP-100C）を用いて測定した。なお，試験体の変 位は， 2 つの変位計の読み取り值の平均值を採用し た。

\section{3. 結果と考察}

\section{1 単調加力試駼結果}

本報では, 論旨の展開のわかりやすさを優先し， 始めに2.2節で記した単調加力試験の結果を報告す る。試験により得られたせん断力ー変位関係を Fig. 4 に示す。なお, 縦軸のせん断力は, 試験体 1 体あ たり（すなわち，接合部 2 か所での合計）の值であ る。いずれの試験体においても, 加力初期では急激 にせん断力が増加し, $1.7 \mathrm{kN}$ 付近で傾きが小さくな った。その後は, ほぼ一定の傾きでせん断力が増加 しながら, 3.5 4.7 kN で最大荷重に至り，その後
はせん断力が低下した。なお，最大荷重時の変位は おおよそ15〜25 mm であった。

この結果を用いて, クリープ試験における応力レ ベルの基準值を決定した。本研究では, 降伏耐力 $P_{y}$ を基準值に採用することとした。降伏耐力 $P_{y}$ は 以下の手順25)により決定した（Fig. 5 ）。1）せん 断力-変位関係上の縦軸值が $0.1 P_{\text {max }}$ と $0.4 P_{\text {max }}$ に対 応する 2 点を直線で結び，これを直線 I とする。な お, ここで $P_{\text {max }}$ は最大荷重を示す。2) 同様に, $0.4 P_{\text {max }}$ と $0.9 P_{\text {max }}$ に対応する 2 点を直線で結び, こ れを直線 II とする。 3 ）直線 II をせん断力ー変位 関倸に接するように平行移動させ，これを直線 III とする。4）直線 I と III の交点を通り, 横軸に平 行な直線 IV をひく。直線 IV とせん断力－変位関 係との交点を降伏点とする。これにより求めた降伏 点を, Fig. 4 の白プロットで示す。いずれの試験体 でも，上述の傾きが小さくなるところよりも少し上 側に位置する結果となった。なお，この傾向は筆者 $ら^{26)}$ が釬接合部で報告した内容と同様であった。

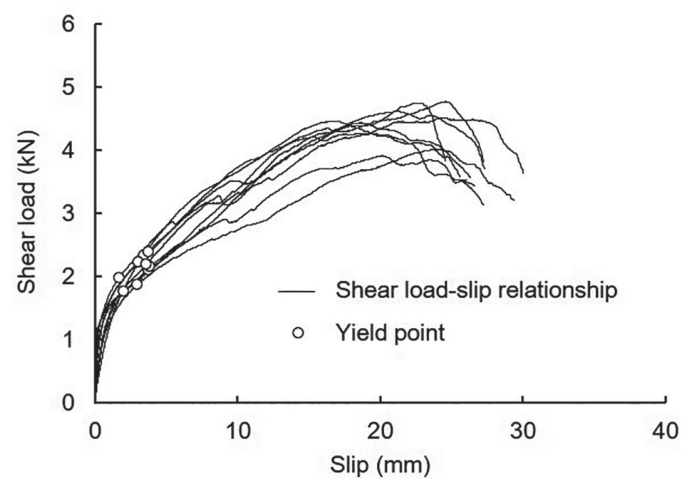

Fig. 4. Load-slip relationships obtained by the monotonic-loading test.

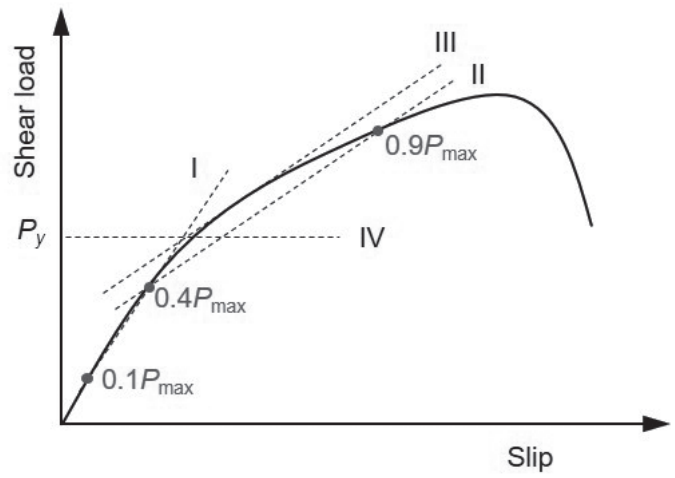

Fig. 5. Method for determining the yield load $P_{y}$. 


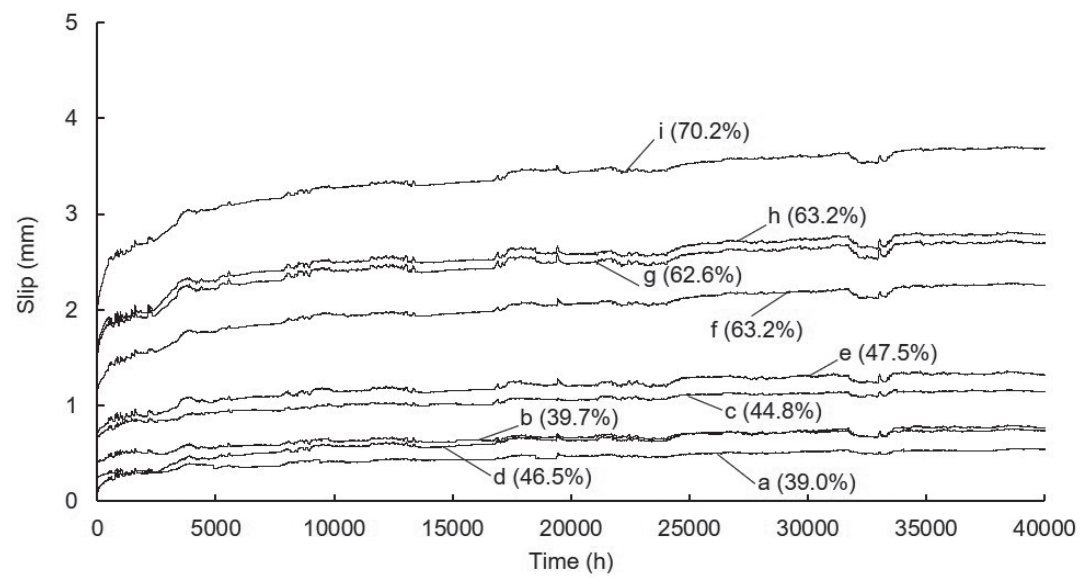

Fig. 6. Slip-time relationships obtained from the creep tests. The symbols and values in parenthesis refer to test specimen and stress level (see Table 1).

各試験体で得られた降伏耐力 $P_{y}$ の值を Table 1 に 示す。また，これを基に算出した応力レベルを併せ て示す。なお，応力レベルは，実際に載荷した荷重 $P_{a}$ を降伏耐力 $P_{y}$ で除した結果を百分率で示したも のである。これによれば，今回のクリープ試験の応 カレベルは39.0 70.2\%であった。また，いずれの $P_{a}$ でも $P_{y}$ を大きく下回っていることから, クリー プ試験は線形粘弾性の範囲内で行われたと判断でき る。

なお, 部材を対象とした長期荷重性能を調べる際 は，最大荷重を応力レベルの基準に採用することが 一般的であるが27,28)，今回は降伏耐力を基準に採用 した。部材の場合は文献の強度值等を用いておおよ その最大荷重を求めることができるが, 接合部の場 合は最大荷重を知るには一般的に試験を要する。一 方, 降伏耐力であれば, 例えばヨーロッパ型降伏理 論を用いれば，文献に記載される特性值からおおよ その值を求めることができる。したがって, 実際に 試験を実施していない（あるいはデー夕等を保有し ていない）場合であっても，接合部のクリープ限度 の扮扮よその值をイメージするには，降伏耐力を基 準とした方が適していると考えたためである。

\section{2 クリープ試験結果}

クリープ試験により得られた変位一時間関係を Fig. 6 に示す。図中の記号は各試験体 (Table 1 参照) を示しており，また，括弧内の值は応力レベルを示 している。いずれの試験体でも，時間が経過するに つれて, 指数関数的に変位が増加した。載荷初期で は曲線的に変位が増加しているが，4000～5000時間 付近からは直線的に増加する様子がうかがえる。グ
ラフ中のおおよそ2500〜4000時間の範囲では，変位 の増加が大きくなっている。これは，この期間は恒 温恒湿室の調整のため, 一時的に湿度が高くなった ためである。調整中に温度湿度データロガーの故障 があったために正確な值が不明であるが，この期間 は最大で湿度が75\%程度まで上昇した可能性があ る ${ }^{24)}$ 。なお，4000時間以降は調整が完了し，相対湿 度 $65 \pm 3 \%$ の範囲内で推移している。

応力レベルに注目すると, 応力レベルが低いほど 変位の值は小さくなる傾向が見られた。しかしなが ら，試験体 $\mathrm{d}$ のように，応力レベルが46.5\%である ものの, 試験体 b p (それぞれ $39.7 \%, 44.8 \%$ ) よりも変位が小さくなる試験体も現れた。同様に, 試験体 $\mathrm{f}$ と h は同じ応力レベルではあるものの, 変 位には載荷期間全体を通して $0.5 \mathrm{~mm}$ ほどの変位の 違いが現れた。以上から, 応力レベルは接合部の変 位に大きく影響する要因ではあるものの, 試験体の バラツキに左右されるところも大きいことが明らか になった。このバラッキの原因として，例えば，ク リープ試験時と単調加力試験時のビスの打ち込み位 置に拀ける部材での局所的な物性に違いがあったこ と, あるいは, ビス打ち込み時に部材内部で生じて いる微小な破壊の様子が両試験時で違っていたこと などが考えられる。しかしながら今回の研究では, バラツキの原因の断定には至らなかった。

\section{3 クリープ限度の推定}

前節でも報告した通り，変位一時間関係は，時間 の増加に伴って曲線的に変位が増加する範囲と直線 的に増加する範囲に分けられる。そこで, 直線的に 増加する範囲において, その傾きを求めた。ここで 
は, 載荷時間が20000時間に到達すると, 変位一時 間関係は完全に直線的な挙動に移行している（遅延 時間を過ぎている）と考え，横軸值20000～40167時 間でのデータプロットを対象に，最小二乗法による 直線回帰をした。なお，沢田 ${ }^{12)}$ が “クリープ変形 の増加速度がほぼ一定となるのは200時間程度” と の見解を残していることを鑑みると，解析対象が 20000時間以降という設定は，完全に直線的挙動に 移行しているとの判断に足ると考えている。この傾 きと応力レベルとの関係を Fig. 7 のプロットで図示 する。これによれば，応力レベルが大きくなるにつ れて，傾きも大きくなっている。このプロットに対 して直線回帰をしたところ，図の点線が描かれ，決 定係数は 0.970 と高い值を示した。続いて，この回 帰線の横軸切片に注目する。横軸切片は, 傾きが 0 になる応力レベルを意味しており，すなわち，載荷 を継続させても変位が増加しないことを意味してい る。本研究では，これをクリープ限度であると定め た。Fig. 7 中の回帰式を用いれば，本試験でのビス 接合部のクリープ限度は $27.6 \%$ となった。

ビス接合部のクリープ限度が得られたところで, 本研究でのクリープ限度に対する考え方を, 既往の 考え方と比較する。本研究では, 単位時間における 変位の増加が 0 となる応力レベルをクリープ限度と 定めて打り，これは，杉山年)の“継続荷重を受け てもクリープが休止する荷重の最大值” と同義であ ると考えられる。しかしながら，值の決定方法が異 なり，杉山はクリープ関数と応力レベルの関係にお ける傾斜の異なる二つの折れ線の交点としているこ とに対し, 本研究の方法は, 先述の回帰線の外挿に より值を推定するものであり, これは, Sugimoto $ら^{29)}$, Sasaki $~^{30)}$, 筆者ら ${ }^{31)}$ がかつて疲労限度の推 定で試みた方法に考え方が似ている。上述の“クリ

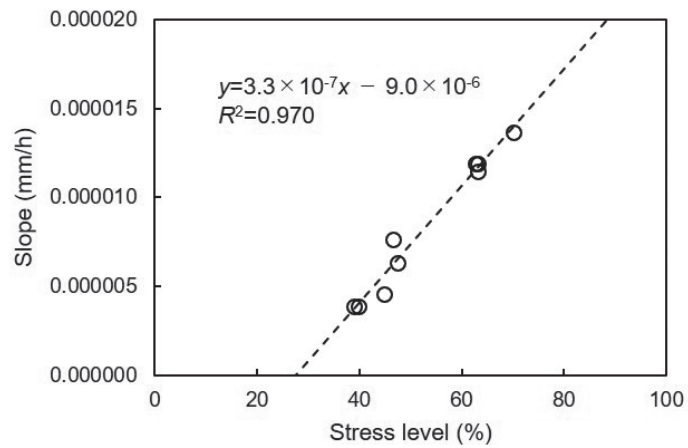

Fig. 7. Slope-stress level relationship. The intersection of the regression line (dotted line) and the horizontal axis identifies the creep limit.
ープの休止”を現すのであれば，本研究の方が適し ているように考えられるが，一方，結果を得るまで に長い時間を要する点で実用性は低い。これの克服 のためには，例えば，変位一時間関係において完全 な直線的変形挙動への移行の時間を判断する手法を 考案し，より小さな載荷時間でのデータプロットで も，正確な傾きを求められることが重要と考えられ る。なお，本試験結果に対して杉山の方法を試みた が，クリープ関数一応力レベル関係における折れ線 の交点が現れず，クリープ限度は決まらなかった。 これは, 今回のクリープ試験での応力レベルの最低 值（39.0\%）がクリープ限度を上回っているためと 考えられる。

\section{4. 結 論}

ビス接合部のせん断クリープ特性の把握を目的と して，主材をヒノキ，側材を構造用針葉樹合板とし たビス接合部のクリープ試験を実施した。試験によ り得られた変位一時間関係を見ると, 試験開始から お打よそ4000～5000時間までは曲線的な挙動が見ら れたが，それ以降では直線的に変位が増加する挙動 が現れた。この挙動をもとに, クリープ限度の推定 を試みた。この直線的な挙動における傾きと応力レ ベルの関係を調べると，散布図で一直線上にプロッ トされることを発見し，その回帰直線を用いて単位 時間における変位の増加が 0 となる応力レベルを求 めた。これによれば，本試験でのビス接合部試験体 のクリープ限度は, 降伏耐力を基準とした場合の $27.6 \%$ あるることが推定された。ただし，本研究は 恒温恒湿条件下で試験をして得られた結果である。 木質構造物での利用の際は水分非平衡の状態にある ことから，メカノソープディブ変形が起こりえるこ とを考えると, クリープ限度はより低くなる可能性 がある。

\section{謝辞}

本研究は平成25年森林整備加速化・林業再生事業 （地域材利用開発事業分）の一環として実施したも のである。また，せん断クリープ試験を実施するに あたり, 静岡大学農学部住環境構造学研究室の当時 在籍学生諸君に多大なご協力をいただいた。ここに 記して謝意を示す。

\section{文献}

1）小松幸平, 瀧野眞二郎, 東丸真一：スギ小幅板 や挽き割材等で構成された耐力壁の水平せん 断性能. 木材研究 - 資料 34, 167-186 (1998). 
2）秋山信彦, 稲山正弘, 小野塚真規, 河原重明, 清 水 武: 鋼板ビス留め式 2 材合せ木質ラーメ ン構造の柱梁接合部に関する研究 - パネルシ アーを考慮した集成材-鋼板間ビス接合の解析 式の提案一。目本建築学会構造系論文集 79 (703), 1337-1346 (2014).

3）張 雲翔, 小林研治, 安村 基：脚部を引きボ ルト抢よびビス留め金物で緊結したCLT耐力 壁の地震時挙動. 木材学会誌 65(2), 71-82 (2019).

4）村上素子, 福山 弘, 北村治男, 原田浩司, 鈴木

圭, 清水庸介, 後藤隆洋 : 木造軸組工法によ るフランジ継手のある合板充腹梁の実大曲げ 試験. 日本建築学会技術報告集 21(48), 585590 (2015).

5）藤田和彦, 稲山正弘, 李 元羽, 成田敏基 : 単 板積層材ストレストスキンパネルのクリープ 特性 その 1 実大部材の検討. 日本建築学会大 会学術講演梗概集, 構造 III, 2014, pp. 347-348.

6）小林研治：木質構造におけるビス接合部の力 学特性. 木材工業 64(6), 252-257 (2009).

7）河村 進, 稲山正弘, 李 元羽, 成田敏基 : 単 板積層材ストレストスキンパネルのクリープ 特性 その 2 接着ビス接合部の検討. 日本建築 学会大会学術講演梗概集, 構造 III, 2014, pp. 349-350.

8）大木秋緒, 小林研治, 安村 基, 北村治男：合 板を側材に用いたビス接合部のクリープ試験. 日本建築学会大会学術講演梗概集, 構造 III, 2014, pp. 481-482.

9）小林研治：木質構造におけるビス接合部の現 状と今後の課題. 木材学会誌 61 (3), 162-168 (2015).

10）杉山英男：クリープ試験。“建築構造学大系 22 木構造”, 彰国社, 東京, 1971, pp. 28-31.

11）例えば川田雄一：材料の機械的性質. “材料力 学 - 基礎と強度設計 - ”, 裳華房, 東京, 2003, p. 11.

12）沢田 稔：木材梁に関する研究（第 4 報）曲 げクリープ試験（1）。林業試験場研究報告 98 , 85-116 (1957).

13）桑村 仁：木材の縦圧縮クリープ限度 一鉄骨 木質構造の研究 その $14-$. 日本建築学会構造 系論文集 77 (681), 1691-1700 (2012).

14) Sugiyama, H.: The creep deflection of wood subjected to bending under constant loading, Transactions of AIJ 55, 60-70 (1957).
15）松本和茂, 大橋義徳：各種道産部材の実大曲 げクリープ試験. 日本木材学会北海道支部研 究発表講演集 38, 5-8 (2006).

16）中島史郎：クリープ関数を用いた荷重継続時 間の調整係数 試験評価方法の適用範囲. 第 66 回日本木材学会大会研究発表要旨集, 名古屋, 2016, D27-07-1100.

17）松本悠杜, 中島史郎：クリープ関数の分析に 基づく木質構造材料のクリープ限度の推定法 に関する研究. 日本建築学会大会学術講演梗 概集, 構造 III, 2016, pp. 75-76.

18）荒武志朗, 深田 学: 宮崎県産スギを用いた CLTの長期性能（その 2) クリープ関数によ る荷重継続時間の調整係数の推定（荷重比の 検討). 第67回日本木材学会大会研究発表要旨 集, 福岡, 2017, D18-P1-16.

19）高梨隆也, 大橋義徳, 石原 亘, 松本和茂：ク リープ関数によるカラマツCLTのクリープ限 度の推定. 日本建築学会大会学術講演梗概集, 2018, pp. 351-352.

20）中野隆人：線形粘弾性理論. “木質の物理”, 日 本木材学会編, 文永堂出版, 東京, 2007, pp. 113132.

21) Jang, S., Polensek, A.: Theoretical models for creep slip of nailed joints between wood and wood-based materials. Wood Sci. Technol. 23, 237-249 (1989).

22) Jan, S., Fujimoto, Y., Mataki, Y.: Viscousviscoelastic models for creep of nailed joints using plywood, particleboard and medium density fiberboard as sheathing materials. Mokuzai Gakkaishi 39(4), 418-427 (1993).

23）大木秋緒, 小林研治, 安村 基, 北山治男 : 合 板を側材に用いたビス接合部のクリープ試験. 日本建築学会大会学術講演梗概集, 構造 III, 2014, pp. 481-482.

24）小林研治, 田中 孝: 加湿器と除湿器の設置 による恒温恒湿室化を試みた実験室の温湿 度制御性能評価. 木材工業 70(10), 428-431 (2015).

25）河合直人：接合部の標準試験方法. “木質構造 設計規準 - 同解説 - 許容応力度 - 許容耐力設 計法 - ", 日本建築学会編, 丸善出版, 東京, 2011, pp. 367-369.

26）小川敬多, 原田真樹, 渋沢龍也, 宮本康太：各 種構造用面材を用いた釘接合部の一面せん断 特性と変形性状の把握. 木材学会誌 64(4), 
139-148 (2018).

27）例えば平成12年 5 月 31 日建設省告示第1446 号：建築の基礎, 主要構造部等に使用する建 築材料並びにこれらの建築材料が適合すべき 日本産業規格又は日本の農林規格及び品質に 関する技術的基準を定める件. 建設省 (2000). (最終改正：令和元年11月 6 日国土交通省告示 第763号).

28）例えば2018年枠組壁工法建築物 設計の手引 き・構造計算指針編集委員会：材料及び接合 部の許容応力度等を定める試験・評価方法と その解説. “2018年枠組壁工法建築物構造計算 指針”，一般社団法人日本ツーバイフォー建築 協会編, 丸善出版, 東京, 2018, pp. 263-306.
29) Sugimoto, T., Yamasaki, M., Sasaki, Y.: Fatigue and hysteresis effects in wood-based panels under cyclic shear load through thickness. Wood Fiber Sci. 38(2), 215-228 (2006).

30) Sasaki, Y., Oya, A., Yamasaki, M.: Energetic investigation of the fatigue of wood. Holzforschung 68(7), 843-848 (2014).

31) Ogawa, K., Shimizu, K., Yamasaki, M., Sasaki, Y. : Fatigue behavior of Japanese cypress (Chamaecyparis obtusa) under repeated compression loading tests perpendicular to the grain. Holzforschung 71(6), 499-504 (2017). 